KOPECZKY RITA

\title{
A PERZSA KIRÁLYSÁGIDEOLÓGIA EGY ELEME XENOPHÓN ANABASISÁBAN
}

Az Anab. I. 4. 17-8 Kyros seregének az Eufráteszen való átkelését írja le, ill. az ezzel kapcsolatos reflexiókat a lakosság körében. Az elbeszélés egyetlen párhuzamos szövegben (Ktésias, Plutarchos) sem található meg. A szöveg így szól: Taṽ $\alpha \delta \varepsilon$

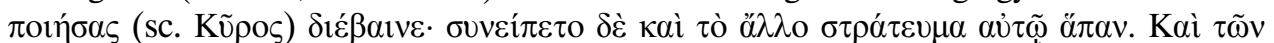

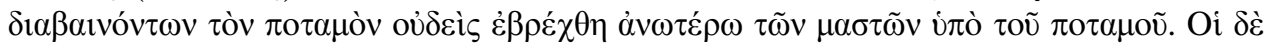

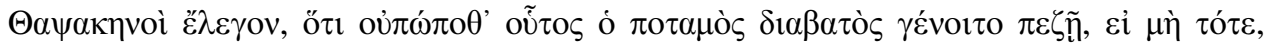

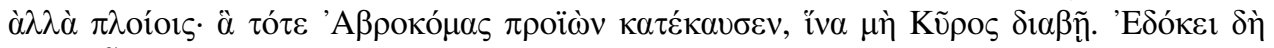

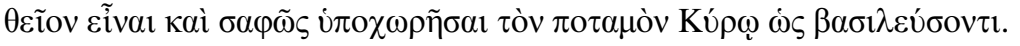

A szövegrész vallástörténeti értelmezésére H. Smilda tett kísérletet ${ }^{1}$, helyesbíteni kívánva az addig uralkodó véleményt, miszerint az Eufrátesz pusztán tisztelettel kívánt adózni a leendő királynak. Ó abból indult ki, hogy az ókori Keleten elterjedt képzet szerint az egyes földi dolgoknak megvan az égi megfelelőjük, így a királynak a főisten, az Eufrátesznek egy égi folyó. Ahogy tehát az égi folyó engedelmeskedik a főistennek, úgy a földi a királynak. Ez a magyarázat, jóllehet helyesen jár el abban, hogy a szöveg értelmezését az ókori Kelet vallási képzeteinek körében keresi, túlegyszerúsíti a problémát azzal, hogy az égi-földi megfelelés elvét a néhány, hivatkozásaiban is megtalálható pontról mechanikusan (és bizonyára nem eléggé megalapozottan) kiterjeszti. ${ }^{2}$ Egy másik kísérlet W. Knauth nevéhez fúzódik³: ô egyfajta, az

${ }^{1}$ H. Smilda: Varia III. De quadam religione orientali. Mnemosyne 54 (1926) 267.

${ }^{2}$ Smilda valószínúleg jó nyomon jár, amikor a Xenophón-szövegrészlethez hozzákapcsolja a Hér. VII. 35-öt és 54-et is, azaz azt a két jelenetet, amelyekben Xerxés megkorbácsoltatja és megbilincselteti a Helléspontost, ill. késóbb, italáldozat bemutatása után, annak vizébe dob egy kelyhet, egy arany borkeve-

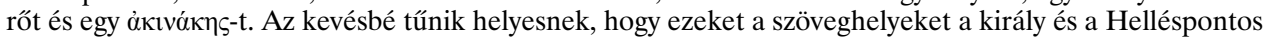
közti húbérúr-vazallus kapcsolatból magyarázza - különösen az utolsót, arra alapozva, hogy a perzsa királyok a barátaikat és udvaroncaikat szokták ḋkıvókns-szel megajándékozni. Azt azonban nem veszi figyelembe, hogy az effajta ajándékozásról szóló szövegek a fegyvert egyszer sem említik együtt borkeverôvel, mindössze egyszer kehellyel (Ail. Var. hist. I. 22), annál többször nyaklánccal és karkötővel (Xen. Anab. I. 8; - ráadásként ruhával: Ktésias, FGrHist 3C 688 F 26, Ail. Var. hist. I. 22, Themist. Eis Konst. 36c; - és lóval: Xen. Anab. I. 2) - amely utóbbiak egyikét sem dobja Xerxés a tengerbe. 36.

${ }^{3}$ W. Knauth: Das altiranische Fürstenideal von Xenophon bis Ferdousi (Wiesbaden, 1975) 118. n. 
uralkodóhoz kötődô manaisztikus erő („orenda”) képzetét hozza fel magyarázatul, amely a királynak minden természeti erő (így folyók és állatok) feletti hatalmában nyilvánul meg. Bizonyára lehetséges azonban a tárgyalt történetnek helyesebb vallástörténeti értelmezése is.

Az a mitikus motívum, miszerint a királyságra kiszemelt egyént valamiféle víz segíti a neki rendelt uralom megszerzésében, és/vagy akadályozza ezt meggátolni kívánó ellenségeit, az iráni $\chi$ varənō fogalommal függ össze, amely a legitim királyság isteni ismertetôjele és feltétele. Több, az indoeurópai múltban gyökerező mítosz összefüggésével alá lehet támasztani, hogy a ævarənō-nak valamiképpen köze van a vízhez, s ily módon a víznek hatalmában áll beleszólni királyságok és királyok sorsának alakulásába.

A ұvarənō szó egy minden legitim királyhoz hozzátartozó, isteni eredetú jelenséget, kisugárzást, felhatalmazást jelent, amely a király villám- és túztermészetével is összefügg. ${ }^{4}$ Bizonyítja az uralkodó kiválasztottságát, ámde csak addig, amíg a birtokosa méltó rá ${ }^{5}$ - vagy nem akad nála méltóbb. Megléte vagy hiánya eleve determinálja a király boldogulását. A katonai sikerek záloga, ezenkívül biztosítja az ország jólétét és az esőt. ${ }^{6}$ Tulajdonképpen azonos a király, sôt az ország szerencséjével. Az ókori sémi nyelvekben a palmyraiban a $g d, g d$, a punban és héberben a $g d$, a nabateusban a $g d$ ', a hatraiban a gnd' szóval adják vissza, ami kb. szerencsét jelent (pl. gd' $d y d w r$ ' - Gaddā dī Dūrā — „Dura-Europos Tychéje”). ${ }^{7}$ Ugyan-így a görög és

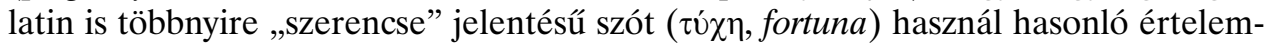
ben. ${ }^{8}$

Külsóleg látható jelekben is megtestesül: jelképei az arany ${ }^{9}$, a fény ${ }^{10}(\mathrm{pl}$. keletiráni érméken és festményeken a király fejét körülvevố aureola) ${ }^{11}$, a kos (pl. a Sāsā-

${ }^{4}$ G. Widengren: Die Religionen Irans (Stuttgart, 1965) 43-4. A xwarenō-ra vonatkozó gazdag irodalomból 1. mindenekelótt H.W. Bailey: Zoroastrian Problems in the Ninth-Century Books (Oxford, 1943) 1-51 (Farrah), 52-77 (Farrah outside the Zoroastrian Books). Bailey a xvarənō 19 korábbi értelmezését ismerteti. L. továbbá H. S. Nyberg: Die Religionen des alten Iran (Leipzig, 1938) 71 skk.; E. Herzfeld: Zoroaster and his world, I-II. (Princeton, 1947) 176-186 (Hvarnah), 562-583 (Apām nāpāt). Herzfeld a ұvarənō következő értelmezését adja: „,tyché, fortune', later ,fortune, wealth'”. Legutóbb: P. Lecoq: Le mot farnah- et les Scythes. CRAIBL 1987. 671-682.

${ }^{5}$ Pl. az avesztai XIX. Yaštban (34) Yima királyt hazug beszéde miatt hagyja el a $\chi$ varənō $-\mathrm{s}$ ettól kezdve sebezhetôvé válik ellenségeivel szemben, végül pedig egyikük szétfúrészeli (46).

${ }^{6}$ Widengren 54-7.

${ }^{7}$ Ch. F. Jean-J. Hoftijzer: Dictionnaire des inscriptions sémitiques de l'ouest (Leiden, 1965) 47. Ennek megfelelóen a középperzsa írásban a fogalmat a ג ideogramma jelöli. Vö. H. F. J. Junker: Das Frahang i Pahlavik (Leipzig, 1956) 5.

8 Vö. Borzsák I.: Népmese? Királytörténet? Rituális dráma? Dragma (Bp., 1994) 80: baktriai görög érmék Tyché alakjában ábrázolják a ұvarənō-t. (A tanulmány eredeti megjelenése: MTA Nyelv- és Irod. tud. OK 33 (1982) 103-110.)

${ }^{9}$ Borzsák: Dragma 81.

${ }^{10}$ Borzsák: Dragma 81, Widengren 58.

${ }^{11}$ Widengren 56, 153, 313, 343. 
nida dinasztia alapítási mondájában $)^{12}$, a Vāruyan-madár ${ }^{13}$. A $\not$ varənō jelöli meg a kiválasztott iráni fejedelmeket, ezenkívül attribútuma Ahura Mazdā-nak és még több isteni lénynek, az első három mitikus királynak és egyéb hôsöknek. ${ }^{14}$ Különösen sokszor szerepel ZaraOuštrával kapcsolatban. ${ }^{15}$ Utóbb egyes fejedelmi nemzetségeknek is lehetett $\chi$ varəno-juk. ${ }^{16}$

A ұvarənō-ról a legtöbb információt az Avesztában, a XIX. Yaštban ${ }^{17}$ találjuk, amely sorra veszi az isteni legitimáció eme jelének birtokosait és ennek birtokában véghezvitt tetteiket; ezek a világrend (Aša) helyreállításának, ill. fenntartásának szolgálatában állnak. A szöveg a ðvarənō-t többféle módon is kapcsolatba hozza a vízzel. ${ }^{18}$

Az elsố szöveghely (45-54) szerint a ұvarənō, azaz a hatalom megszerzése volt a tétje a jó és rossz szellem (Spuntā Mainyū és Anrā Mainyū) harcának. Mindkét küzdő fél kiküldi képviselôjét, akik feladata ennek megszerzése, de egyikük sem meri megragadni az ellenfél fenyegetései miatt. Ekkor Apąm Napāt, a vizek elosztója kap

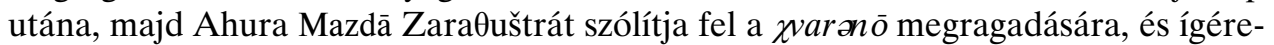
tet tesz, hogy annak birtokosát felruházza a papi, katonai és gazdasági hatalommal egyaránt. ${ }^{19}$

Apąm Napāt hasonló néven (Apāṃ Napāt) ${ }^{20}$ szerepel a Rog-vedában (2. 35), melyben a vízben rejlő túzzel azonosították: a vízmerítés nem lehetséges az ô akarata ellenére. ${ }^{21}$ Ezt a szerepét a kutatás egyrészt az olajjal (naphtha) azonosítja ${ }^{22}$, másrészt a villámmal ${ }^{23}$. Ez utóbbi fontos és széles körben elterjedt motívuma a perzsa királyideológiának $^{24}$ : a monda szerint villám csapott a gyermek Mithridatésbe (Plut. Quaest. conv. I. 6. 2) 25, sốt Olympiasnak, Nagy Sándor anyjának álmában is ez szerepel (Plut. Alex. 2. 3) ${ }^{26}$. Apąm Napāt egyes kutatók szerint valószínúleg azonos a kelta Nechtannal és a római Neptunusszal ${ }^{27}$. Ez érthetôvé teszi azt, hogy miért lehet szoros kapcsolatban egymással a ұvarənō és a víz. Az édes- és tengervíz közti megkülönböztetést ebben az esetben figyelmen kívül lehet hagyni (vö. Serv. ad Georg. IV. 29: Neptunus fluminibus et fontibus et aquis omnibus praeest).

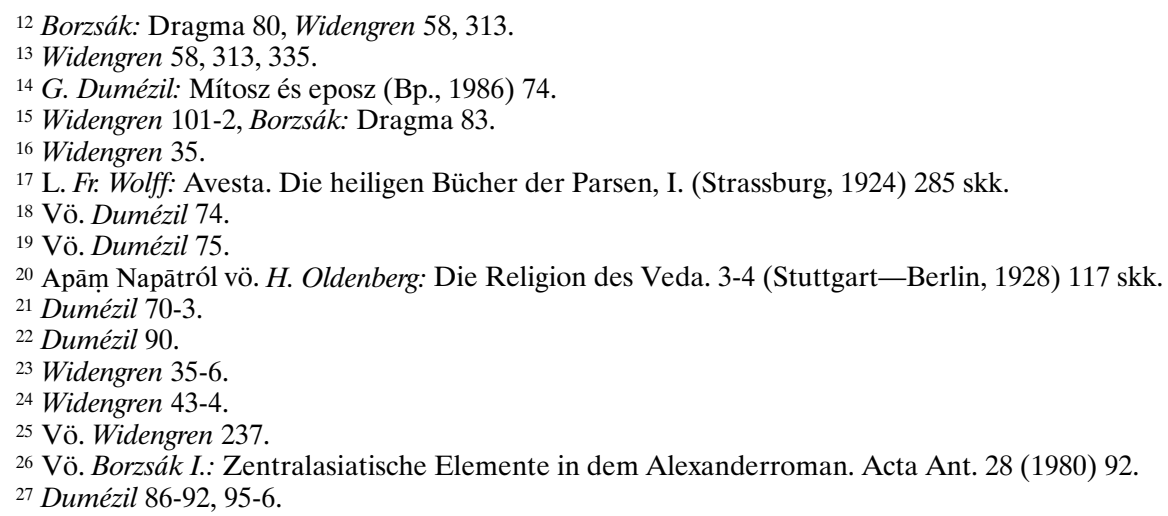


A másik szöveghely a XIX. Yaštban (65-9) a ұvarənō-t a Kąsaoya-tóval hozza összefüggésbe ${ }^{28}$, amelybe több folyó ömlik. Ehhez a tóhoz kötődik egyébként Astvațrratának, egy „messianisztikus” szerepú, az isteni legitimációval ugyancsak rendelkező személynek a fellépése, akinek feladata, hogy a világot megszabadítsa a hazugságtól (91-7). A Kąsaoya-tavat önmagából alkotó folyóról, a „fehér fodrokat vetô, sok árvizet okozó, pompás, csillogó” Haētumantról így szól a himnusz (XIX. Yašt, 68): „Ihm... ist die kavische Herrlichkeit ( $\chi$ varənō) zuteil; und es befindet sich in ihm... soviel kavische Herrlichkeit, daß er hier die nicht-arischen Länder (alle) auf einmal fort und wegschwemmen könnte."29

Tehát a భvarənō jellemző tartózkodási helye valamiféle víz ${ }^{30}$, többnyire egy-egy meghatározott tó vagy folyó. Az egyik szövegben a $\chi$ varənō mint egy bizonyos elhatárolható létezố foglal helyet egy tóban, a másikban viszont inkább valami mérhetô dologként, erőként jelenik meg, amivel az adott víz kisebb vagy nagyobb mértékben telítve van. Valószínúleg erre a telítettségre, ill. annak megnövekedésére reagál áradással a Haētumant.

G. Dumézil három, egymással összefüggő mítoszt hoz fel a három dolog kap-

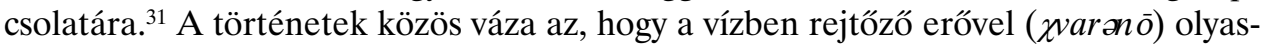
valaki próbál kapcsolatba lépni, aki arra méltatlan; a víz azonban támadóan lép fel a bitorlóval szemben, és megakadályozza céljának elérésében. ${ }^{32}$

1. A XIX. Yaštban megkezdett mítosz folytatása (55-64, vö. még 82). A turáni Frạrasyan, az irániak esküdt ellensége eltökéli, hogy kihalássza a ðvarənō-t a Vourukaša-tóból, jóllehet ahhoz csak az árja országoknak és Zara日uštrának van joga. Beugrik a tóba, hogy úszva közelítse meg. Ám az elillan elóle, és menekülés közben egy lefolyást húz a tóból. Ez még kétszer ismétlődik, még két új „folyó” ered. Fraqrasyan végül megunja, és lemond a további kísérletezésról.

2. Egy több változatban fennmaradt kelta (ír) mítosz: Dinnshenchas, azaz mitikus földrajz a Boyne folyóhoz. Nechtan istennek, Bóand asszony férjének van egy titkos kútja, amelyben egyfajta sugárzás lakozik. Ez egyedül a kút gazdájára és annak három pohárnokára nem jelent veszélyt, de annál inkább azokra, akik hazugsággal

${ }^{28}$ Vö. Dumézil 76. Utólag ezt a tavat azonosították a Vourukaša-tóval, ahová Apąm Napāt a zwarənō-t rejtette (Dumézil 467. n. 15).

${ }^{29}$ Wolff 294. 142-3.

${ }^{30}$ Widengren 35; H. Kleinknecht: Herodot und die makedonische Urgeschichte. Hermes 94 (1966)

${ }^{31}$ Dumézil 75-82, 100-14.

32 Vö. Dumézil 115-9. - Nyilván az sem véletlen, hogy Aischylos Perzsák c. drámájában (495-507) az istenség hasonló módszerrel vesz elégtételt Xerxés hybriséért: a Hellasból menekülő perzsa sereg útját keresztező Strymón folyó egy éjszaka alatt befagy (október közepén vagy november elején!), ám miközben a sereg átkel, a nap felolvasztja a jeget, s így a próbálkozás katasztrófába fullad. Az, hogy ez az esemény valóban megtörtént volna, valószínútlen, és források sem említik — de mint költối lelemény érdekes egybecsengést mutat témánkkal. 
közelítenek hozzá. Bóand megcsalja a férjét Dagda főistennel, és fiút szül attól; majd hogy hamis bizonyítékot szerezzen ártatlanságára, háromszor körbejárja a kutat. Erre a kút vizéből három hullám lép ki, amelyek megcsonkítják, majd üldözôbe veszik az asszonyt, de csak a tengerparton érik utol. Ebből lesz a Boyne folyó, amelyből a világ összes jelentős folyója táplálkozik.

3. Egy római exmítosz, amely számunkra ismert formájában annyira historizált, hogy alig ismerhető fel, hogy valaha mítosz volt (Liv. V. 15-7, Dion. Hal. XII. 11-7 stb.). Ez az Albai-tó áradásáról szól, ami Veii ostroma idején esett, és annak volt köszönhetô, hogy a tó partján lévő Iuppiter Latiaris-templomhoz kapcsolódó szertartásokat az erre kirendelt tisztviselő́k elhanyagolták. Egy jóslat szerint amíg a víz eléri a tengert, Veii nem győzhető le. Miután a rómaiak elvezették a vizet és kiengesztelték az istent, bevették a várost. (Az utóbbi mozzanat Dumézil szerint már a historizálásból eredő hozzátoldás az eredeti mítoszhoz..33)

A fenti motívum pozitív formában is megtalálható több nép több elbeszélésében. Vázlata a következô: X, a királyságra kiválasztott személy (többnyire isteni jóslatra vagy felszólításra, csellel) sikeresen elragadja a $\chi$ varənō-t Y-tól, a jelenlegi uralkodótól — az, hogy ezt meg tudja tenni, azt bizonyítja, hogy ezentúl $\mathrm{X}$ a jogos tulajdonos. Y üldözteti X-et, hogy visszaszerezze, amit elvesztett. X-et azonban valamiféle víz segíti a menekülésben, $\mathrm{Y}$ embereit pedig ugyanez a víz gátolja meg abban, hogy utolérjék. ${ }^{34}$ A következő mítoszok erre a szerkezetre épülnek. ${ }^{35}$

1. Perdikkasnak, Témenos fiának, a makedón dinasztia alapítójának története Hér. VIII. 137-8-ból. Két bátyjával együtt számúzöttként érkezik Argosból a felsőmakedóniai Lebaiába, amelynek királya pásztorként alkalmazza óket. Perdikkasnak (nyilván nem véletlenül) éppen az aprómarha, tehát a birka és kecske jut.

A királyné felfigyel arra, hogy a Perdikkas számára dagasztott kenyér mindig kétszer nagyobbra kel az átlagosnál. A király megérti a jelet, és felszólítja a testvéreket, hogy távozzanak. Mikor azok a bérüket kérik, a király a füstnyíláson át a padlóra vetülő napfénnyel akarja kifizetni őket „nesze semmi, fogd meg jól” alapon. Perdikkas elfogadja a fizetséget: körbevési a fényfoltot a késével, három adagot a ruhája öblébe tesz belőle, majd távoznak. (A ұvarənō átvétele ezzel megtörtént.)

A király késôbb észbe kap, és lovasokat küld utánuk, hogy öljék meg ôket; ám

${ }^{33}$ Dumézil 109-14.

${ }^{34}$ Knauth (uo.) felhívja a figyelmet két Šāhnāme-helyre, amelyek egyike (VIII. 3 - beosztás $R$. Levy (ford.): The Epic of the Kings. Shah-Nama the National Epic of Persia by Ferdowsi [Chicago, 1967] nyomán) - leszámítva azt, hogy magát a xvarənō-t ezzel kapcsolatban nem említi — egy hasonló folyami átkelést beszél el: a turániak elól menekülő Kai Xosrau és útitársai kelnek át a megáradt Óxoson (miután a képtelen árat követelő hajókölcsönző megjegyezte, hogy egy folyónak aztán mindegy, hogy király vagy rabszolga akar-e átkelni rajta!), míg üldözőik erre a bravúrra már nem képesek.

${ }_{35} \mathrm{Az}$ 1. és 3. számú történetet már Kleinknecht összekapcsolja a ұvarənō-val, a másodikat Borzsák teszi hozzá (Dragma 79-86 és Elemente 85-9). 
egy folyó, miután Perdikkasék átláboltak rajta, hirtelen úgy megárad, hogy az üldö-

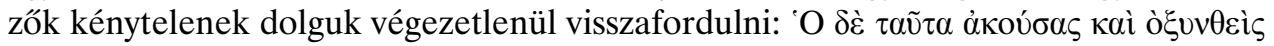

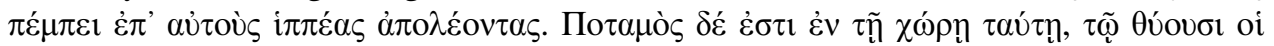

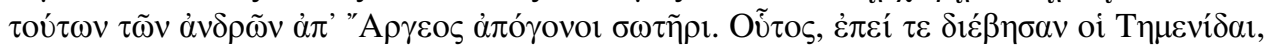

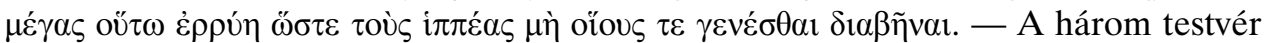
ezután megérkezik arra a helyre, amelyről kiindulva megkezdik uralmuk megalapozását.

2. A Nagy Sándor-regény egy jelenete (II. 13-5 az L kéziratban). Ammón isten megjelenik Nagy Sándornak álmában, és arra biztatja, hogy inkognitóban, saját követeként látogasson el Dareios udvarába, hogy a döntő csata időpontja felól érdeklődjön. Így is lesz. Útban odafelé Nagy Sándor átkel egy Stranga nevú, egy stadion széles folyón. Ennek a folyónak különleges adottságai vannak. Éjszakára befagy, nappal felenged, és olyan erôs sodrása lesz, hogy képtelenség rajta átkelni: Oũ̃os $\delta \grave{\varepsilon}$

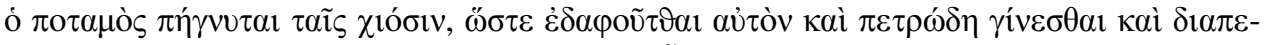

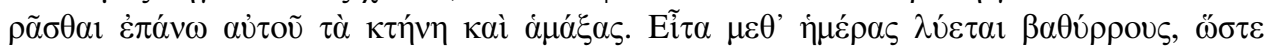

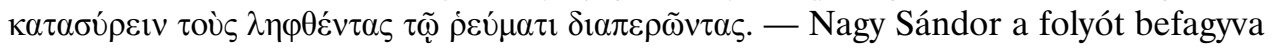
találja; átkel rajta, megérkezik Dareios udvarába, ahol kis híján istennek nézik. A perzsa király lakomára hívja, ahol a jelenlevők elcsodálkoznak a jövevény apró termetén, nem tudván, hogy az égból való túxๆ lakozik benne (!).

Ivás közben az álkövet a kezébe kerülő aranykelyheket sorra eltulajdonítja. Amikor Dareios ennek az okát tudakolja, az arra hivatkozik, hogy Nagy Sándor oda szokta ajándékozni a vendégeinek a kelyheket, amelyekből isznak. Egy időre megfagy a levegô, majd hamarosan felismerik a jövevényt, úgyhogy annak menekülnie kell.

Dareios nemsokára magához tér meglepetéséből, és fegyvereseket küld a vendég üldözésére. Sötét az éjszaka, de a menekülőnek megvilágítja az utat az, ami nála van (az eredeti szövegváltozatban a kelyhek — azaz a $\chi v a r ə n \bar{o}-$, a javítottban egy perzsa kapuőrtől rabolt fáklyák), míg üldözői közül egyesek szakadékokba zuhannak. Végül Nagy Sándor odaér a még mindig befagyott Strangához. Az épp csak addig marad befagyva, míg ô át nem ér; aztán olyan gyorsan enged fel, hogy a lovát is

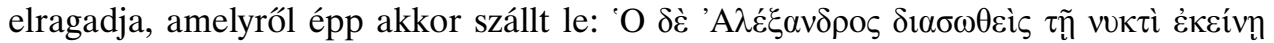

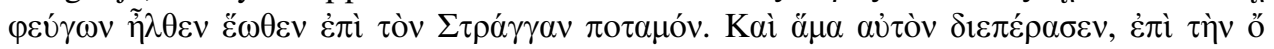

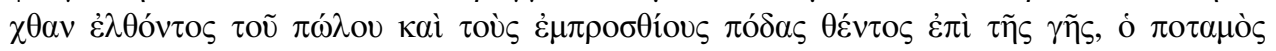

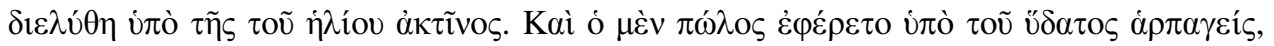

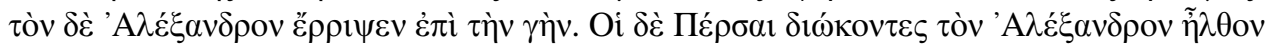

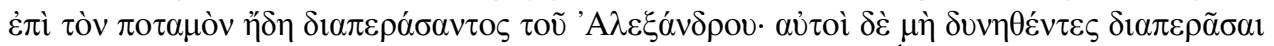

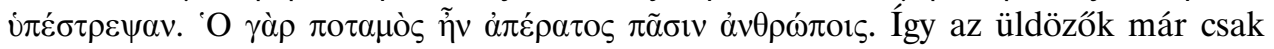
Nagy Sándor szerencséjéről számolhatnak be otthon.

3. A Sāsānida-dinasztia alapítási mondája ${ }^{36}$, amelyet a Kār-nāmak-i Artaðšēri

36 Vö. Kleinknecht 142-3, Widengren 310-3, Borzsák: Dragma 80. 
Pāpakān c. középperzsa regény dolgoz fel. Az utolsó parthus király szolgálatában álló Ardašīr egy jóslat miatt megszökik a király egyik ágyasával együtt, aki jókora aranykészletet menekít magával a kincstárból. Útközben két asszonnyal találkoznak, akik azt tanácsolják Ardašǐrnak: siessen a tengerhez, mert amint beleteszi a lábát, biztonságban lesz ellenségeitől. A király üldözi őket, de hiába. Elóbb azt a hírt kapja róluk, hogy egy nagy kos rohan utánuk, később már azt, hogy a kos Ardašìr lován vele együtt ül. A főpap felvilágosítja, hogy a kos a Kayanidák xvarənō-ja, és hogy ezzel a hatalom sorsa eldőlt — ez pedig hamarosan igazolódik.

Tehát a víz szokatlanul engedékeny, ill. ellenséges magatartása ezekben az elbeszélésekben a ঝvarənō jogos birtoklásával vagy (immár) jogtalan kergetésével áll összefüggésben.

A Nagy Sándor-hagyományból még egy „vizes” jelenetet meg kell említeni, amely valószínúleg ugyancsak ebbe a sorba tartozik — de az általunk vizsgált Xenophón-helyhez biztosan kapcsolódik. Ez pedig a pamphyliai tengeren való átkelés jelenete. A racionálisabb szerző́k szerint Nagy Sándor az apályt figyelte meg és használta ki, utólag pedig csodás színben tüntette fel az eseményeket, mások azonban arról beszélnek, hogy isteni parancsra visszavonult, ill. kettévált előtte a tenger. ${ }^{37}$

Ezeknek a mítoszoknak, elsősorban pedig a második, pozitív típusnak a háttere elótt kell megvizsgálni a Xen. Anab. I. 4. 17-8-at is. Annak, hogy az elbeszélés egyedül Xenophónnál van meg, csak az egyik oka az, hogy a többi szöveg a másik fél, azaz a nagykirály szempontjából nézi a dolgot, s ezért kevésbé lehet ismerôs azzal, mi történt, mi nem történt Kyros seregével az úton. A másik ok minden bizonnyal ideológiai természetû: a „másik fél” nem szívesen tudott olyasmirôl, ami Kyros trónigényének legitimitását támogatta volna, legyen az akár valóság, akár propaganda.

A xenophóni elbeszélésben közel ugyanaz az alaphelyzet, mint a Perdikkas- és a Nagy Sándor-mondákban: egy trónon levő király és egy reménybeli hatalomátvevő szembenállásába szól bele egy vízrajzi objektum. A víz viselkedéséból, mint a fenti mondákból-mítoszokból kitûnt, következtetni lehet arra, hogy a hozzá közeledő fél hatalmi vagy önigazolási igénye jogos-e (akkor a víz mellette áll), vagy pedig alkalmatlan arra, amit el akar érni (ez esetben a víz ellenállásával kell számolnia).

A mítosz itt nem jelenik meg teljes egészében. Hiányzik a ұvarənō megszerzésének motívuma. A helyzet annyiban fordított, hogy a ,jövendó király” nem defenzívában, hanem offenzívában van. Ezért más alakot ölt az ellenfél általi akadályoztatás, valamint ezzel együtt a víz állásfoglalása is. A folyó nem az üldözőket hátráltatja,

37 Idevágó szöveghelyek: Plut. Alex. 17. 6-8 (kritikusan a csodás átkelésben hívő történetírókról), Strabón XIV. 3. 9 (apály esetén járható gázlón kelnek át úgy, hogy a víz csak a köldökükig ér), Me-

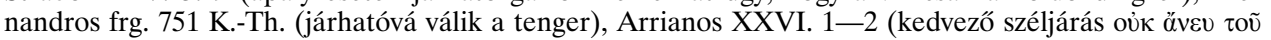

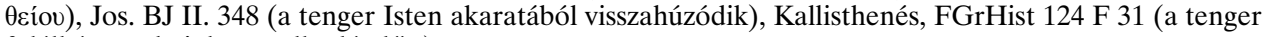
föláll és meghajol az uralkodó előtt). 
hanem az előnyomulót segíti szokatlan viselkedésével — annak ellenére, hogy az ellenfél képviselője, Abrokomas, aki a folyó szokásos természetével számol (ti. azzal, hogy azon nem lehet gyalogosan átkelni), kísérletet tesz a trónköveteló megállítására (felgyújtja a hajókat). A történet vége pedig, mint tudjuk, ezúttal nem igazolta vissza a víz jóslatát.

Természetesen, mielőtt még Xenophónt mint mythographust kezdenénk vizsgálni, nem szabad figyelmen kívül hagyni, hogy hogyan találkozott ô ezzel a mítoszszal. Xenophón történetíró, és elsősorban azt írja le, amit ő maga tapasztalt a görög sereg tagjaként. Ez pedig nem több, mint a gyalogos átkelés ténye (ami valóban nem mindennapi, hiszen Nagy Sándor ugyanitt, Thapsakosnál hidak segítségével kelt át). Lévén pedig katonaember, ráadásul görög, nem lehetne csodálni azt sem, ha a perzsa mitologémák teljes nem-ismeretében figyelmen kívül hagyná a thapsakosiak megjegyzését az eseménnyel kapcsolatban.

Az pedig, hogy mégsem így történt, valószínúvé teszi azt, hogy Kyros nem mulasztotta el propagandacéljainak szolgálatába állítani a különleges átkelést, méghozzá éppen abban az összefüggésben, amit fentebb próbáltam vázolni - és bizonyára a mítosz teljes formájának felhasználásával. Természetesen ennek a propagandisztikus alkalmazásnak csak a képzetkört ismerő, tehát perzsa környezetben van értelme és létjogosultsága; ennek ellenére legalábbis a Xenophón által közölt formában eljutott a görög seregrészhez is. Sőt valószínúbb, hogy a királysággal kapcsolatos megjegyzés nem a thapsakosiaktól, hanem Kyrostól vagy az ô legbelsőbb köreiből származik. 